\title{
The Role of Services and Facilities in Population Sustainability of Rural Settlements (Case Study: The Villages in Central Region of Birjand city)
}

\author{
O papel dos serviços e instalações na sustentabilidade populacional de \\ assentamentos rurais (estudo de caso: as aldeias da região central da cidade \\ de Birjand)
}

Hossein Hashemi'

Hamid Jafari"

Mohammad Ali Ahmadian"'I

\begin{abstract}
The studies show that today, the process of the social-economic changes and the increasing dynamism and replacement of the human groups have led to the changes in the rural areas. Therefore, the issue that basically, which factors have been effective on population sustainability in the rural settlements has been always arisen. The current study also has sought to find answer to this question. The current study is of descriptive-analytical type in terms of the methodology. The statistical population of the current study is all the villages in central zone of Birjand City which have had a population of more than 100 people (89 villages) according to 2016's census. In order to determine the sample size, firstly 9 rural settlements in central zone of Birjand City which had the highest population decrease during 2006 to 2016, were selected. Then, based on the number of households in these 9 villages (691 households), 247 households were chosen according to Cochran Formula, to fill in the questionnaire, and finally, the samples were distributed by the stratified random sampling based on the ratio of each village's household share. The descriptive-inferential method by the use of the SPSS was utilized for data analysis. The results indicated that the services and facilities have had a significant role in population sustainability of the rural settlements.
\end{abstract}

Keywords: Population sustainability; Rural settlements; Employment; Income

I PhD Student, Department of Geography and Rural Planning, Mashhad Branch, Islamic Azad University, Mashhad, Iran - h.hashemi@gmail.com

"Assistant Professor, Department of Geography and Rural Planning, Mashhad Branch, Islamic Azad University, Mashhad, Iran - Jafari1421@mshdiau.ac.ir

I'Associate Professor, Department of Human Geography, Mashhad Branch, Islamic Azad University, Mashhad, Iran - m.a.ahmadian@gmail.com 


\section{Resumo}

Os estudos mostram que hoje, o processo de mudanças socioeconômicas e o crescente dinamismo e substituição dos grupos humanos têm levado a mudanças nas áreas rurais. Portanto, sempre se levantou a questão de que basicamente quais fatores têm sido efetivos na sustentabilidade da população nos assentamentos rurais. $O$ presente estudo também procurou encontrar respostas para essa pergunta. $O$ presente estudo é do tipo descritivo-analítico em termos de metodologia. A população estatística do presente estudo é de todas as aldeias da zona central da cidade de Birjand que tiveram uma população de mais de 100 pessoas (89 aldeias) de acordo com o censo de 2016. Para determinar o tamanho da amostra, primeiro foram selecionados 9 assentamentos rurais na zona central da cidade de Birjand, que tiveram a maior queda populacional entre 2006 e 2016. Em seguida, com base no número de domicílios nessas 9 aldeias (691 domicílios), 247 domicílios foram escolhidos de acordo com a Fórmula de Cochran, para preencher o questionário e, finalmente, as amostras foram distribuídas por amostragem aleatória estratificada com base na razão de cada parte da casa da aldeia. O método descritivo-inferencial pelo uso do SPSS foi utilizado para análise dos dados. Os resultados indicaram que os serviços e instalações tiveram um papel significativo na sustentabilidade da população dos assentamentos rurais.

Palavras-chave: Sustentabilidade da população; Assentamentos rurais; Emprego; Renda 


\section{Introduction}

According to many theoreticians and analysts, achievement of development models and institutionalizing them in the countries, especially developing countries such as Iran, would not be possible without paying attention to the rural areas. The village is the footstone of development and an engine for the countries advancement. Less developed or developing countries can be named that have managed to institutionalize or plan for the multilateral, sustainable, and balanced development strategies without taking into consideration the role of rural population (MOTEI LANGROUDI, 2013, 24). It seems that paying attention to all factors that have increased the population sustainability and emphasizing on them, and lack of such factors which lead to the increase in population instability in the rural settlements, are especially important in the form of a generality and an integrated system. Today, achievement of a sustainable development is the main objective of the development planners and policy-makers. Since $28.5 \%$ of the country's population live in the villages and the urban societies also cannot host more populations due to problems such as the poverty, unemployment, and suburbanization, paying serious attention to the villages and properly planning for their sustainable development and population sustainability in the rural settlements are essential. On the other hand, the 15-34 age group makes up the largest section of the migrants from the villages (STATISTICS CENTER OF IRAN, 2011, 8), and the village-to-city migrations are the outcome of historical requirement which is created as the result of the de-economization of the agricultural activities due to the population boost and improvement of the exploitation methods in the villages on the one hand, and the growth of the industrial activities and the demand for the young labor force in the cities. Meanwhile, migration of those who get separated from their villages and come to the cities has had some effects on both the home and destination. The most important aspect of these changes in the villages is the evacuation of them, which in addition to irreparable cultural changes, leads to the decrease in productivity rate and its adversaries directly affect the Gross National Product (GDP). Also, it can be said with certainty that the aspects of migration which is usually done due to the economic problems and decrease in the income as well as the 
sustainable employment, are not limited to the rural settlements and involve the whole society, systematically. Therefore, the recognition of the effective factors on prevention of people migration, and rural settlements sustainability can reduce the unwanted effects of such consequences (MAHDAVI et al., 2014). Regarding the mentioned reasons, the necessity to conduct a comprehensive study on this subject is felt. This study can identify the effective factors on population sustainability of the villages in the central zone of Birjand City. The achievements of this study can be useful in future planning of rural development, and can also be used by the responsible organizations and institutions for development such as the South Khorasan general governorship, district governorship of the central zone, and the village administrators, as well as the Islamic Revolutionary Housing Institution. Finally, since in the area under study, no studies have been conducted on this subject, the current study can be a new and innovative one. In addition, it should be noted that based on the research by the author, similar studies so far have focused on the issue of the migrants, while in the current study, the population residing in the rural settlements of the central zone of Birjand City has been studied.

\section{Theoretical Framework}

Rural settlement: the rural settlements in one general definition, and based on the definitions provided by the Statistics Center, are divided into three categories as regular, temporary, and nonresidential. Today, the rural development and the population sustainability in the rural settlements in the developing countries face several challenges, since the past strategies in terms of rural development have not been as successful and they have failed to solve problems such as the poverty, employment, healthcare, food security, and environmental sustainability. These strategies have also been unsuccessful in distribution of the benefits from the growth and development and caused various problems in these countries (BAHMANI et al., 2016, 11).

The effects of services and facilities on population sustainability of the rural settlements: Paying attention to the villages and provision of proper services for them is important, be it due to the necessity of expansion of productive activities or consideration 
for the social justice which leads to the development sustainability, or depiction of the future profile of the intrinsic development in these settlements. The issue of organizing the villages has been arisen in the Fourth Civil Plan pre-revolution in different forms such as rural civil fields, integration of the dispersed villages, merging the dispersed villages, optimal settlement, etc. and each of these strategies have been implemented in different periods. The distance between the urban life and rural life desirability and even the different geographical zones of the country, has made the rural migration as one of the dilemmas of the country. Subsequently, if these distances are not reduced, and the attraction of the rural settlements is not increased, the migration trend would be worsened. The presence of the administrative services which can strengthen the connections between the rural society and the government and upper-hand institutions, and increase the sustainable security ratio plays an important role in rural settlements population sustainability (FATAEl et al., 2017, 56). Generally, it can be said the view on the constituent components and elements of the rural system shows that most rural societies are integrated corpuses, i.e. different components of the rural life such as the natural components (territory, soil, vegetation cover, rangeland), economical components (agriculture, industry, services, and investment), and social components (life patterns, population growth, customs, ethnicity, sociocultural differences and adversaries) are all closely tied to each other (CANIRS, 2015, 43).

The social and cultural consequences of migration and instability in the rural settlements: The investigations show that the young villagers start migration from the village to the city in the search of a better life, and the social dynamism leads to the increase in various social capabilities among them. The young, through escaping from the existing traditional norms, seek to reach the individual autonomy and freedom of choice, and save themselves from the social loneliness and isolation in the rural areas which is accompanied with hard and constant physical labor, and they choose the cities to find social status and obtain dignity and stimulating leisure. However, the studies show that such migrations would bring about negative social consequences for the young villagers and the cities, such as the lack of social integrity and expansion of the social anomalies in the cities. The most important social consequence of the village-to-city migration of the youth is the improvement in education status and their knowledge and awareness. The cities, having more and better 
educational facilities, can flourish the young villagers' talents and ingenuity. Among the other consequences, the improvement of the leisure time (presence of various libraries in the cities and cultural places), the increase in cultural exchange, and the change in clothing and speaking styles can be named.

\section{Review of the Related Literature}

KOHNE POUSHI AND SHAYAN (2017) in an article titled "the investigation of the reasons of village-to-city migration in the Khaw and Mirabad sitricts of Mariwan City" showed that the inappropriateness of the components predisposing the creation and development of non-agricultural sector, especially the social, economic, and political components lead to the widespread village-city replacements, specifically that of the young and educated forces to the urban areas and consequently, the loss of economic opportunities, especially in the agricultural sector. It has also led to the unsustainability of the rural settlements in most regions of Iran.

GHASEMI SIANI (2016) in his doctoral thesis titled "determination of the relationship between the population and sustainable rural development: case study of Mashhad City" showed that through realization of the sustainable development in the villages under study, the population average is increased. It seems that the existing unsustainability in different aspects of development has led to doubts in capabilities of these areas even in maintaining their current capabilities. In this regard, the panning for improvement of the development level in different aspects is necessary for the low-population villages.

BAHMANI AND HATAMI (2015) in an article titled "investigation of the reasons of villagers' migration to the cities" which was a type of domestic division in terms of the location, discussed the different migration theories such as those of Orthly, Louis, Fee Rais, and correlation. The results of this study showed that the rural repellents play a more important role in rural migration than the economic, natural, agricultural, social, and cultural aspects.

SHAHNAZ (2010) in a study titled "investigation of above-ten-year-old female villagers' migration to cities" has dealt with evaluation of such migration. The results of this 
study showed that the rural women's marriage and having a townsman husband is among the most important reasons behind migration of the women to the cities. Also, other rural women migrated due to the lack of job opportunities. Therefore, creation of small employment enterprises, especially in the rural areas, can prevent the migration of the villagers besides increasing their income.

AGBOLA et al. (2010) in an empirical study dealt with the analysis of the international immigration of the Philippine labor force. In this study, in order to decrease the results deviation, the study has been conducted in a period from 1975 to 2005. The results indicated that the unemployment of the low-educated people and the population density are among the main reasons of immigration from the Philippines. Also, the government instability adversely affect the rate of immigration.

\section{Methodology}

The current study is of applied type in terms of the objective and descriptive-analytical in terms of the nature and method. The statistical population of the current study is all the villages in central zone of Birjand City which have had a population of more than 100 people (89 villages) according to 2016 's census. In order to determine the sample size, firstly 9 rural settlements (10\% of the total villages) in the central zone of Birjand City which had the highest population decrease during 2006 to 2016 , were selected. Then, based on the number of households in these 9 villages (691 households), 247 households were chosen according to Cochran Formula, to fill in the questionnaire, and finally, the samples were distributed by the stratified random sampling based on the ratio of each village's household share.

Table 1 - The spatial distribution of the questionnaires in the sample villages

\begin{tabular}{l|c|c|c|c|c}
\hline Row & Village name & $\begin{array}{c}\text { Rural } \\
\text { district }\end{array}$ & $\begin{array}{c}\text { Reduction } \\
\text { percentage }\end{array}$ & $\begin{array}{c}\text { Total number of the } \\
\text { households }\end{array}$ & $\begin{array}{c}\text { Number of } \\
\text { samples }\end{array}$ \\
\hline 1 & Goloonbad & Alghoorat & 36 & 126 & 45 \\
\hline 2 & Naghanj & Alghoorat & 47 & 123 & 44 \\
\hline 3 & Asnan & Shakhnat & 41 & 65 & 23 \\
\hline 4 & Roshnavand & Fesharrood & 42 & 54 & 19 \\
\hline
\end{tabular}




\begin{tabular}{l|c|c|c|c|c}
\hline 5 & Siskan & Kahshang & 38 & 48 & 17 \\
\hline 6 & Alghar & Kahshang & 40 & 50 & 18 \\
\hline 7 & Roghayeh Abad & Kahshang & 38 & 50 & 18 \\
\hline 8 & Khazan & Shakhan & 40 & 98 & 35 \\
\hline 9 & Behdan & Bagheran & 40 & 77 & 28 \\
\hline \multicolumn{2}{l}{ Total } & & 651 & 247 \\
\hline
\end{tabular}

\subsection{Data Collection Instrument, Validity, and Reliability of the Study:}

The researcher-made questionnaire whose validity has been determined by the Delphi Technique and its face and formal validity has been approved by the experts of the fields, has been used in the current study to collect the data. The reliability of this study has been measured by the use of Cronbach's alpha coefficient.

Table 2 - Measurement of the questionnaire's Cronbach's alpha coefficient

\begin{tabular}{l|l}
\hline Research variables & $\begin{array}{l}\text { Cronbach's alpha } \\
\text { coefficient }\end{array}$ \\
\hline Facilities and services & 0.876 \\
\hline
\end{tabular}

Since the Cronbach's alpha coefficient is higher than 0.7, the reliability of all three sections is optimal and the internal validity is also approved.

Table 3 - The results of reliability testing of the research variables

\begin{tabular}{l|c|c}
\hline \multicolumn{1}{c|}{$\begin{array}{c}\text { Research } \\
\text { variables }\end{array}$} & $\begin{array}{c}\text { Kolmogorov-Smirnov } \\
\text { Test }\end{array}$ & p-value \\
\hline Facilities and & 0.348 & 0.889 \\
services & & \\
\hline
\end{tabular}

Regarding the obtained results and since the $p$-value obtained for the tests is above our significance level, which is $\alpha=0.05$, the normality of the data is confirmed. 


\section{Results}

\subsection{Effects of communicative facilities on prevention of population migration:}

Table 4 - Effect of communicative and telecommunication facilities on sustainability of population

\begin{tabular}{l|c|c}
\hline $\begin{array}{c}\text { Options statistical } \\
\text { index }\end{array}$ & Frequency & Percentage \\
\hline Very low & 4 & 1.6 \\
\hline Low & 20 & 8.1 \\
\hline Average & 36 & 14.6 \\
\hline High & 83 & 33.6 \\
\hline Very high & 104 & 42.1 \\
\hline Total & 247 & 100 \\
\hline
\end{tabular}

Regarding the results of the above table, $75.7 \%$ of the participants think that the effect of communicative and telecommunication facilities on sustainability of population in the village is high and very high.

\subsection{The Effects of Appropriate Roads on Rural Population Sustainability:}

Table 5 - Effect of appropriate connection roads on sustainability of population

\begin{tabular}{l|c|c}
\hline $\begin{array}{c}\text { Options } \\
\text { statistical index }\end{array}$ & Frequency & Percentage \\
\hline Very low & 1 & 0.4 \\
\hline Low & 19 & 7.7 \\
\hline Average & 54 & 21.9 \\
\hline High & 87 & 35.2 \\
\hline
\end{tabular}




\begin{tabular}{l|c|c}
\hline Very high & 86 & 34.8 \\
\hline Total & 247 & 100 \\
\hline
\end{tabular}

Regarding the results of the above table, $70 \%$ of the participants think that the effect of appropriate connection roads on sustainability of population in the village is high and very high.

\subsection{The Effects of Public Transportation Facilitation on Rural Population Sustainability:}

Table 6 - Effects of public transportation facilitation on population sustainability

\begin{tabular}{l|c|c}
\hline $\begin{array}{c}\text { Options statistical } \\
\text { index }\end{array}$ & Frequency & Percentage \\
\hline Very low & 3 & 1.2 \\
\hline Low & 14 & 5.7 \\
\hline Average & 43 & 17.4 \\
\hline High & 99 & 40.1 \\
\hline Very high & 88 & 35.6 \\
\hline Total & 247 & 100 \\
\hline
\end{tabular}

Regarding the results of the above table, $75.7 \%$ of the participants think that the effect of public transportation facilitation on sustainability of population in the village is high and very high.

\subsection{The Effect of Village Environment Improvement on Rural Population Sustainability:}

Table 7 - Effect of improvement of the village environment on sustainability of population

\begin{tabular}{l|c|c}
\hline $\begin{array}{c}\text { Options statistical } \\
\text { index }\end{array}$ & Frequency & Percentage \\
\hline Very low & 7 & 2.8 \\
\hline Low & 28 & 11.3 \\
\hline Average & 55 & 22.3 \\
\hline
\end{tabular}




\begin{tabular}{l|c|c}
\hline High & 74 & 30 \\
\hline Very high & 83 & 33.6 \\
\hline Total & 247 & 100 \\
\hline
\end{tabular}

Regarding the results of the above table, $63.6 \%$ of the participants think that the effect of improvement of the village environment on sustainability of population in the village is high and very high.

\subsection{The Effects of Village Entertainment and Sports Facilities on Rural Population}

\section{Sustainability:}

Table 8 - Effect of entertainment and sports facilities on sustainability of population

\begin{tabular}{l|c|c}
\hline $\begin{array}{c}\text { Options statistical } \\
\text { index }\end{array}$ & Frequency & Percentage \\
\hline Very low & 6 & 2.4 \\
\hline Low & 34 & 13.8 \\
\hline Average & 43 & 17.4 \\
\hline High & 79 & 32 \\
\hline Very high & 85 & 34.4 \\
\hline Total & 247 & 100 \\
\hline
\end{tabular}

Regarding the results of the above table, $66.4 \%$ of the participants think that the effect of entertainment and sports facilities on sustainability of population in the village is high and very high.

\subsection{The Effects of Village Health and Medical Facilities on Rural Population Sustainability:}

Table 9 - Effect of health and medical facilities on sustainability of population 


\begin{tabular}{l|c|c}
\hline $\begin{array}{l}\text { Options statistical } \\
\text { index }\end{array}$ & Frequency & Percentage \\
\hline Very low & 0 & 0 \\
\hline Low & 13 & 5.3 \\
\hline Average & 36 & 14.6 \\
\hline High & 84 & 34 \\
\hline Very high & 114 & 46.2 \\
\hline Total & 247 & 100 \\
\hline
\end{tabular}

Regarding the results of the above table, $80.2 \%$ of the participants think that effect of health and medical facilities on sustainability of population in the village is high and very high.

\subsection{The Effects of Villagers Access to the Veterinary Services on Rural Population}

\section{Sustainability:}

Table 10 - Effect of villagers' access to the veterinary services on sustainability of population

\begin{tabular}{l|c|c}
\hline $\begin{array}{c}\text { Options statistical } \\
\text { index }\end{array}$ & Frequency & Percentage \\
\hline Very low & 5 & 2 \\
\hline Low & 26 & 10.5 \\
\hline Average & 46 & 18.6 \\
\hline High & 81 & 32.8 \\
\hline Very high & 89 & 36 \\
\hline Total & 247 & 100 \\
\hline
\end{tabular}

Regarding the results of the above table, $68.8 \%$ of the participants think that the effect of villagers' access to the veterinary services on sustainability of population in the village is high and very high. 


\subsection{The Effects of Villagers Access to the Educational Services on Rural Population}

\section{Sustainability:}

Table 11 - Effect of villagers' access to the educational services on sustainability of population

\begin{tabular}{l|c|c}
\hline $\begin{array}{c}\text { Options statistical } \\
\text { index }\end{array}$ & Frequency & Percentage \\
\hline Very low & 2 & 0.8 \\
\hline Low & 18 & 7.3 \\
\hline Average & 35 & 14.2 \\
\hline High & 73 & 29.6 \\
\hline Very high & 119 & 48.2 \\
\hline Total & 247 & 100 \\
\hline
\end{tabular}

Regarding the results of the above table, $77.8 \%$ of the participants think that the effect of villagers' access to the educational services on sustainability of population in the village is high and very high.

\subsection{The Effects of Presence of Disciplinal Services and Increase in Security on Rural Population Sustainability:}

Table 12 - Effect of presence of disciplinal services and the increase in security on sustainability of population

\begin{tabular}{l|c|c}
\hline $\begin{array}{c}\text { Options statistical } \\
\text { index }\end{array}$ & Frequency & Percentage \\
\hline Very low & 6 & 2.4 \\
\hline Low & 29 & 11.7 \\
\hline Average & 56 & 22.7 \\
\hline High & 79 & 32 \\
\hline Very high & 77 & 31.2 \\
\hline
\end{tabular}




\begin{tabular}{l|c|c}
\hline Total & 247 & 100 \\
\hline
\end{tabular}

Regarding the results of the above table, $63.2 \%$ of the participants think that the effect of presence of disciplinal services and the increase in security on sustainability of population in the village is high and very high.

\subsection{The Effects of Garbage Collection on Rural Population Sustainability:}

Table 13 - Effect of collection of the garbage on sustainability of population

\begin{tabular}{l|c|c}
\hline $\begin{array}{c}\text { Options statistical } \\
\text { index }\end{array}$ & Frequency & Percentage \\
\hline Very low & 10 & 4 \\
\hline Low & 32 & 13 \\
\hline Average & 61 & 24.7 \\
\hline High & 89 & 36 \\
\hline Very high & 55 & 22.3 \\
\hline Total & 247 & 100 \\
\hline
\end{tabular}

Regarding the results of the above table, $58.3 \%$ of the participants think that the effect of collection of the garbage on sustainability of population in the village is high and very high.

\subsection{The Effects of Presence of Fuel and Energy Distribution Stations on Rural Population Sustainability:}

Table 14 - Effect of presence of fuel and energy distribution stations on sustainability of population

\begin{tabular}{c|c|c}
\hline $\begin{array}{c}\text { Options statistical } \\
\text { index }\end{array}$ & Frequency & Percentage \\
\hline
\end{tabular}




\begin{tabular}{l|c|c}
\hline Very low & 2 & 0.8 \\
\hline Low & 16 & 6.5 \\
\hline Average & 55 & 22.3 \\
\hline High & 72 & 29.1 \\
\hline Very high & 102 & 41.3 \\
\hline Total & 247 & 100 \\
\hline
\end{tabular}

Regarding the results of the above table, $70.4 \%$ of the participants think that the effect of presence of fuel and energy distribution stations on sustainability of population in the village is high and very high.

\subsection{The Effects of Access to the Agricultural and Non-Agricultural Equipment Maintenance Stations on Rural Population Sustainability:}

Table 15 - Effect of access to the agricultural and non-agricultural equipment maintenance stations on sustainability of population

\begin{tabular}{l|c|c}
\hline $\begin{array}{c}\text { Options statistical } \\
\text { index }\end{array}$ & Frequency & Percentage \\
\hline Very low & 14 & 5.7 \\
\hline Low & 26 & 10.5 \\
\hline Average & 57 & 23.1 \\
\hline High & 73 & 29.6 \\
\hline Very high & 77 & 31.2 \\
\hline Total & 247 & 100 \\
\hline
\end{tabular}


Regarding the results of the above table, $60.8 \%$ of the participants think that the effect of access to the agricultural and non-agricultural equipment maintenance stations on sustainability of population in the village is high and very high.

\subsection{Hypothesis Testing:}

It seems that that the facilities and services play an important role in population sustainability of the rural settlements in the area under study.

Table 16 - The t-test results (the effects of facilities and services on the population sustainability of the rural settlements)

\begin{tabular}{c|c|c|c|c|c|c}
\hline \multicolumn{7}{c}{ Test value = 3 } \\
\hline $\begin{array}{c}\text { Number of } \\
\text { participants }\end{array}$ & Variable & Mean & $\begin{array}{c}\text { Standard } \\
\text { deviation }\end{array}$ & $\begin{array}{c}\mathbf{t}- \\
\text { value }\end{array}$ & $\begin{array}{c}\text { Degree } \\
\text { of } \\
\text { freedom }\end{array}$ & $\begin{array}{c}\text { Significance } \\
\text { level }\end{array}$ \\
\hline 247 & $\begin{array}{c}\text { Facilities } \\
\text { and } \\
\text { services }\end{array}$ & 3.92 & 0.69 & 20.80 & 246 & 0.000 \\
\hline
\end{tabular}

Result: regarding the results in table 16, it can be seen that the observed mean value of the effect of services and facilities on population sustainability of rural settlements (20.80) has a significant difference with the standard mean (3), and based on the value of sig $=0.000$, it can be claimed that in the participants' point of view, the services and facilities play a significant role in population sustainability in the rural settlements. As a result, the third hypothesis of the study is approved.

\section{Conclusion}

The results indicated that the services and facilities have a significant effect on the population sustainability of the rural settlements. The findings obtained from the hypothesis testing are in lines with those of Kohne Poushi and Shayan (2017), Ghasemi Siani (2016), Safaei Poor et al. (2016), Kiani et al. (2016), Soleimani et al. (2015), Ejtemaei et al. (2014), 
Ebrahimzade and Aghasizade (2015), Akah and Medvedev (2010) and Dickman (2008). In these studies, the effects of the facilities and services as one of the effective factors in population sustainability of the rural settlements have been approved. Regarding the continuous droughts, dust storms, the dry weather, and shortage of the required infrastructure and facilities in the region, the following and general solution are suggested for population sustainability in the rural settlements of the central Zone of Birjand City:

1- Increasing the facilities and educational and promotional services to use the important capabilities and resources existing in the villages under the study, especially the wind and sunlight energy, and processing of the strategic products such as the saffron, barberry, jujube, and medicinal plants

2- Provision of more services for the villagers to meet their entertainment, sports, and leisure needs

3- Development of the rural roads and provision of the transportation vehicles

4- Creation of the necessary infrastructure and facilities for the villages such as the water supply, health and medical services, educational facilities, bakery, natural gas, oil products distribution station, and Post Bank offices.

5- Provision of the drinking water as well as the water needed for agriculture

6- Expansion of the side agricultural and processing industries, establishment of the industrial zones, and settlement of the industry in rural areas, for employment and profitability

7- Provision of facilities such as the agricultural and non-agricultural equipment maintenance stations

\section{References}

Agobla,Frank w. and Acupan,Angelito B. An Empircal Analysis of International Labour Migration in The Philippines, From: http: www.elsevier.com. locate. ecosys, 2010.

Bahmani, A., Farahani, H., and Jebali, F. "The process of changing the rural settlements into cities and its effects on the citizens' life quality (The case study: Bolbolan Abad Town, Dehgolan City). The Iranian Sociology Journal, summer, No.22, 2016. 
Canirs, D. "Guidelines in the field of social analysis (for planning of rural areas development)", translated by Hooshang Irwani and Alireza Darban Astaneh, Alborz, karaj, Agricultural Training Publications, 2015.

Fataei, E., Oruji, H., Alizade, H., and Azhari, S. The social capability of acceptance of tourism in rural areas, case study: Mesr Village in Khoor Biabanak City, The Journal of Rural Space and Development Economy, No.6, 2017.

Ghasemi Siani, M. The effects of establishment of the industrial estates in the rural areas, 2016.

Kohne Poushi, S.H., and Shayan, H. "The investigation of the reasons of village-to-city migration in the Khaw and Mirabad districts of Mariwan City", Journal of Rural Research and Planning, No.3, 2017.

Mahdavi, M., \& Nazarian, A., and Barani Pesiani, V. "Measurement and evaluation of life quality of the rural households with emphasis on the demographic variables (case study: Ajabshir Town's rural households), the Rural Studies, $5^{\text {th }}$ Year, spring 2014, No.1 (17 consecutive), 2014.

Motei Langroudi, S.H., \& Noorbakhsh, S.M., and Akbarpoor Saranskar, M. "Determination of a proper strategy for population sustainability in the rural settlements (The case study of Soluk Village in Hashtrood City), Housing and Village Environment Quarterly, 142, 2013.

Shahnaz H. Rural to Urban Migration in Pakistan the Gender Perspective ,Pakistan Institute of Development Economics, Working Papers 56, 2010.

Statistics Center of Iran). "The detailed results and primary data and results of the censuses, 2011. 